\title{
Sistem Aplikasi Absensi Berbasis Android Menggunakan Otentikasi Wajah Dan Lokasi (Studi Kasus Di CV. Atmosfer IT Consultan)
}

\author{
Syukron Isrofi ${ }^{1}$, Johny Hizkia Siringo Ringo ${ }^{2}$ \\ ${ }^{1}$ Program Studi Teknik Informatika, Tanri Abeng University, Jakarta, Indonesia \\ syukron.isrofi@student.tau.ac.id \\ ${ }^{2}$ Program Studi Teknik Informatika, Tanri Abeng University, Jakarta, Indonesia \\ johny.hizkia@tau.ac.id
}

Diterima : 31 Agustus 2021

Disetujui : 28 September 2021

\begin{abstract}
Abstrak - CV. Atmosfer IT Consultan merupakan perusahaan jasa pembuatan aplikasi, yang mana mempunyai karyawan lapangan, yang mengharuskan berkunjung kelokasi klien sehingga perlu adanya sistem aplikasi absensi karyawan yang dapat digunakan untuk memantau dan mengelola kehadiran karyawan yang ditugaskan dilapangan, selama ini untuk memantau kehadiran karyawan yang bertugas dilapangan mengandalkan direct message atau panggilan langsung melalui ponsel masing - masing karyawan. Sistem aplikasi absensi berbasis android yang akan dikembangkan ini menggunakan otentikasi wajah dan lokasi menggunakan bantuan library OpenCV dan Dlib Library untuk otentikasi wajah dan Google Maps API untuk deteksi lokasi, serta metodologi yang digunakan dalam pengembangan sistem ini yaitu menggunakan metode Scrum. Pengembangan aplikasi ini diharapkan dapat memberikan solusi untuk perusahaan CV. Atmosfer IT Consultan khusunya dan perusahaan lain pada umumnya untuk memantau kehadiran karyawannya yang bertugas dilapangan ataupun untuk perusahaan yang menugaskan karyawannya bekerja dari rumah karena adanya pemberlakuan PSBB di beberapa wilayah di Indonesia khususnya di DKI Jakarta.
\end{abstract}

Keyword - Library OpenCV, Dlib Library, API

\section{PENDAHULUAN}

CV. Atmosfer IT Consultan merupakan perusahaan yang bergerak dibidang jasa pembuatan aplikasi dan analisa keuangan berbasis website, desktop dan mobile app, dalam implentasi software secara on - site perusahaan mengirim seorang atau beberapa implementor software untuk melatih dan mengimplementasikan software yang sudah dibuat berdasarkan permintaan klien sebelumnya.

Untuk memantau kehadiran karyawan yang bertugas di lapangan, saat ini perusahaan memanfaatkan media direct message menggunakan aplikasi chatting atau melalui panggilan langsung diponsel masing - masing karyawan, dengan metode yang sekarang rawan terjadinya absensi yang tidak valid, seperti halnya jika mengunakan direct message karyawan bisa saja mengaku sudah dilokasi yang ditugaskan tapi sebenarnya belum berada ditempat yang ditugaskan.

Untuk itu diperlukan sistem absensi karyawan yang fleksibel dan mudah digunakan dengan media otentikasi yang valid seperti halnya otentikasi wajah dan lokasi, diharapkan dengan adanya sistem absensi ini, mampu memberikan solusi dalam memantau kehadiran karyawan, serta proses absensi menjadi lebih valid.

Sistem aplikasi absensi ini akan dikembangkan menggunakan platform berbasis sistem operasi Android, karena setiap karyawan di CV. Atmosfer IT Consultan mayoritas menggunakan ponsel dengan sistem operasi tersebut, dengan metode deteksi lokasi menjadi salah satu fitur validasi absensi dan media otentikasi wajah dari pengembangan library Open $C V$ dan Dlib library yang sudah ada sebelumnya. 


\section{TINJAUAN PUSTAKA}

\section{A. Penelitian Terkait}

Beberapa penelitian yang berkaitan dengan perancangan aplikasi menggunakan deteksi lokasi yaitu pada penelitian [1], menggunakan GPS(Global Positioning System) pada ponsel untuk mendeteksi lokasi dan hanya bisa melakukan absensi kehadiran, pada lokasi $\pm 50 \mathrm{~m}$ dari titik kordinat tempat kerja yang sudah ditentukan, pada penelitian yang lain [2], untuk mengembangkan aplikasi deteksi lokasi dapat memanfaatkan fitur Google Maps API(Application Programming Interfaces) untuk mengetahui titik lokasi dan untuk reverse titik kordinat lokasi menjadi alamat bisa memanfaatkan fitur Geocoding API dari Googel Maps API. Sedangkan dalam mengembangkan aplikasi untuk otentikasi wajah pada penelitian [3], untuk aplikasi android, memanfaatkan library dari Open CV dan Java CV untuk mendeteksi wajah dengan jarak maksimal $0.5 \mathrm{~m}$ dengan posisi wajah $\pm 15^{0}$ tegak lurus arah kamera, pada penelitian [4] library Open CV juga digunakan untuk melakukan otentikasi wajah, dan membandingkanny dengan Dlib library, kedua library tersebut memiliki kelebihan dan kekurangannya masing - masing dalam melakukan deteksi dan otentikasi wajah.

\section{B. Sistem Absensi}

Absensi merupakan ketidak hadiran karyawan ketika tidak masuk sesuai jadwal kerja yang ditentukan, jumlah absensi kerja dalam perusahaan menggambarkan pertukaran benefit antara karyawan dan perusahaan sebagai pihak yang memberikan gaji. Sistem sendiri merupakan suatu kumpulan prosedur jaringan yang saling berhubungan untuk mencapai tujuan tertentu. Sistem absensi merupakan prosedur atau aturan dari perusahaan yang harus dilakukan oleh karyawan sebagai bukti kehadiran, baik dalam bentuk media fisik atau digital, yang kemudian di kelola perusahaan sebagai pertukaran benefit yang mana menjadi evaluasi kerja dan perhitungan gaji yang akan diberikan. [5]

\section{Metode Scrum}

Metode Scrum merupakan metode iterative yang mana dengan memecah tujuan akhir menjadi beberapa tujuan kecil pada awal project pembuatan dan mengerjakan tujuan kecil - kecil tersebut. Dalam mengerjakan tujuan kecil tersebut dilakukan pengulangan secara berkala pada software yang dibuat dan sesering mungkin menampilkan hasilnya.

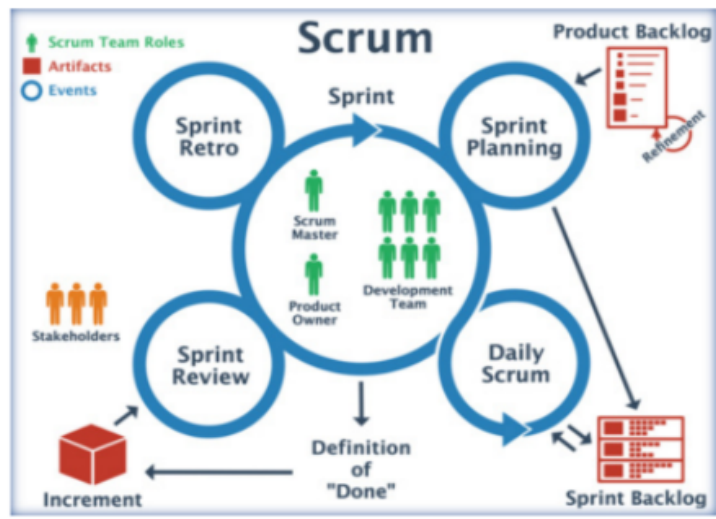

Gambar II.1. Metode Scrum [6]

Metode scrum menggunakan tiga roles / peranan yaitu :

1. Produk Owner bertugas untuk mengatur urusan dengan stakeholder, bertanggung jawab untuk mengkomunikasikan visi dan prioritas untuk tim pengembang

2. Scrum Master bertugas sebagi fasilitator pemilik produk dan tim pengembang, menghilangkan hambatan yang menghalangi tim untuk mencapai tujuannya

3. Development Team bertugas untuk mengatur teknik pengerjaan project dan pembahasan yang lebih rinci

Dalam pengembangan aplikasi atau software dengan metode scrum akan sering melakukan rapat atau pertemuan untuk membahas pengembangan sistem dari awal sampai akhir, proses ini disebut scrum meetings. Scrum meetings merupakan rapat yang dilakukan dalam proses metode scrum, yang difasilitasi oleh scrum master. Selain sebagai fasilitator scrum master juga bertugas memberikan keputusan pada setiap rapat yang diadakan. 
Bagian dalam scrum meetings antara lain :

\section{Sprint Planning Meeting}

Pada setiap awal sprint, pemilik produk (product owner) dan tim akan mengadakan negosiasi untuk menentukan item product backlog yang akan dikerjakan dahulu. Product backlog merupakan daftar kebutuhan atau fitur yang akan dikembangkan pada sistem yang akan dibuat. Pada akhir pertemuan tim akan membagi item product backlog pada daftar sprint task dan membuat komitmen final untuk pengerjaannya. Untuk waktu pengerjaan maksimal sekitar 14-30 hari.

\section{Daily Scrum}

Merupakan meeting yang dilakukan setiap hari yang dilakukan oleh anggota development team untuk melaporkan hasil yang sudah dikerjakan pada hari kemarin, apa saja yang akan dikerjakan hari ini dan hambatan yang dialami dalam proses pengerjaan. Waktu yang dibutuhkan untuk melakukan meeting ini kurang lebih 15 menit.

\section{Sprint Review Meeting}

Merupakan pertemuan yang diadakan untuk demonstrasi produk kepada pemilik produk (product owner) terhadap hasil kerja yang sudah dilakukan. Pertemuan ini dilakukan secara langsung bukan dalam bentuk laporan. Di akhir demonstrasi, product owner akan memberikan evaluasi dan komentar produk mana yang benar benar sudah selesai. Peran scrum master pada tahap ini yaitu menjembatani saran dan masukan dari product owner dan stakeholder terhadap demonstrasi produk yang sudah dilakukan, untuk menjadi item product backlog yang baru.

\section{Sprint Retrospective Meeting}

Pertemuan ini dilakukan pada akhir setiap sprint, untuk membahas hambatan non teknis, seperti perilaku anggota tim selama proses sprint dan mengambil keputusan untuk beradaptasi pada sprint yang akan datang.

\section{Backlog Refinement Meeting}

Pada awal pengerjaan sprint biasanya product backlog item (PBI) yang ditentukan terlalu besar dan perlu ada penyesuaian, sehingga dalam prose sprint tim sedikit mengambil waktu selain mengerjakan tugas yang sudah ditentukan, juga melakukan penyesuaian PBI untuk dikerjakan pada sprint berikutnya. [7]

\section{Google Maps API}

Merupakan layanan dari google yang digunakan untuk mengintegrasikan fitur maps pada pengembangan aplikasi yang akan dibuat, untuk memanfaatkan fitur Google Maps Android $A P I$, yang harus dilakukan adalah mendaftar di situs developers.google.com, kemudian kita akan mendapatkan API Key yang mana nantinya akan digunakan untuk memanggil Google Maps API tersebut. Salah satu fitur dari API ini yaitu Geocoding API yang dapat digunakan untuk mengkonversi alamat menjadi titik kordinat geografis dan bisa juga digunakan untuk reverse geolocation yaitu dari titik kordinat yang didapat kemudian dikonversi menjadi alamat. [2]

\section{E. OpenCV dan Dlib Library}

Open Source Computer Vision Library (OpenCV) merupakan open source computer vision library dan machine learning software library, yang dibuat untuk menyediakan infrastruktur secara umum untuk computer vision dan untuk mempercepat mechine perception dalam produk komersial.

Library ini memiliki 2500 algoritma yang dioptimalkan, yang mencakup algoritma klasik, computer vision dan algoritma machine learning. Algoritma yang disediakan dapat digunakan untuk mendeteksi dan mengenali wajah, mengidentifikasi objek, mengklasifikasikan tindakan manusia dalam video, melacak pergerakan dalam kamera, mengekstrak model objek 3D, menemukan gambar serupa dari database gambar, augmented reality dan sebagainya. Library OpenCV support digunakan untuk sistem operasi Windows, Linux, Android dan Mac OS dan dapat diintegrasikan dengan Phyton, Java, C++ dan lain sebagainya. [8]

Dlib library merupakan library yang ditulis menggunakan bahasa $\mathrm{C}++$ dengan lisensi Open 
Source yang dibuat untuk cross - platform. Pembuat library ini bernama David King yang mana library ini mulai dibuat pada tahun 2002 yang kemudian berkembang pesat untuk banyak kegunaan seperti networking, graphical interfaces, mengolah struktur data yang kompleks, statistical machine learning, image processing, data mining, XML dan text parsing, bayesian network dan lain sebagainya. Dlib library dibuat memuat tujuan portabilitas dan mudah digunakan sehingga kode di Dlib library menjadi seportable mungkin dan tidak mengharuskan menginstall atau mengkonfigurasi apa pun, untuk membantu portabilitas ini semua kode khusus menggunakan API untuk menjembataninya. Lapisan pembungkus API semuanya murni ditulis dengan standar ISO C++. Saat ini library ini dapat digunakan pada OS X, Windows, Linux, BSD, dan HP-UX . [9]

\section{METODE PENELITIAN}

Metode yang digunakan dalam pengembangan dan penelitian pada aplikasi ini yaitu menggunakan metode Scrum, berikut ini adalah beberapa tahapan yang dilakukan dalam metode tersebut:

\section{Product Backlog}

Mengumpulkan kebutuhan sistem berdasarkan pengumpulan data dan analisa sebelumnya, kemudian menentukan priotas dalam pengembangan aplikasi ini, yang mana prioritas awal yaitu pengembangan untuk integrasi otentikasi wajah ke aplikasi dan deteksi otomatis lokasi, kemudian menyusul beberapa product backlog lain seperti data user dan hak akses.

2. Sprint Backlog

Membagi beberapa item dari product block untuk di sprint dan rencana mewujudkan product tersebut. Dalam hal ini product backlog kami kelompokan berdasarkan skala prioritas pengerjaan yang kami bagi menjadi 9 product backlog.

Tabel 1. Product Backlog
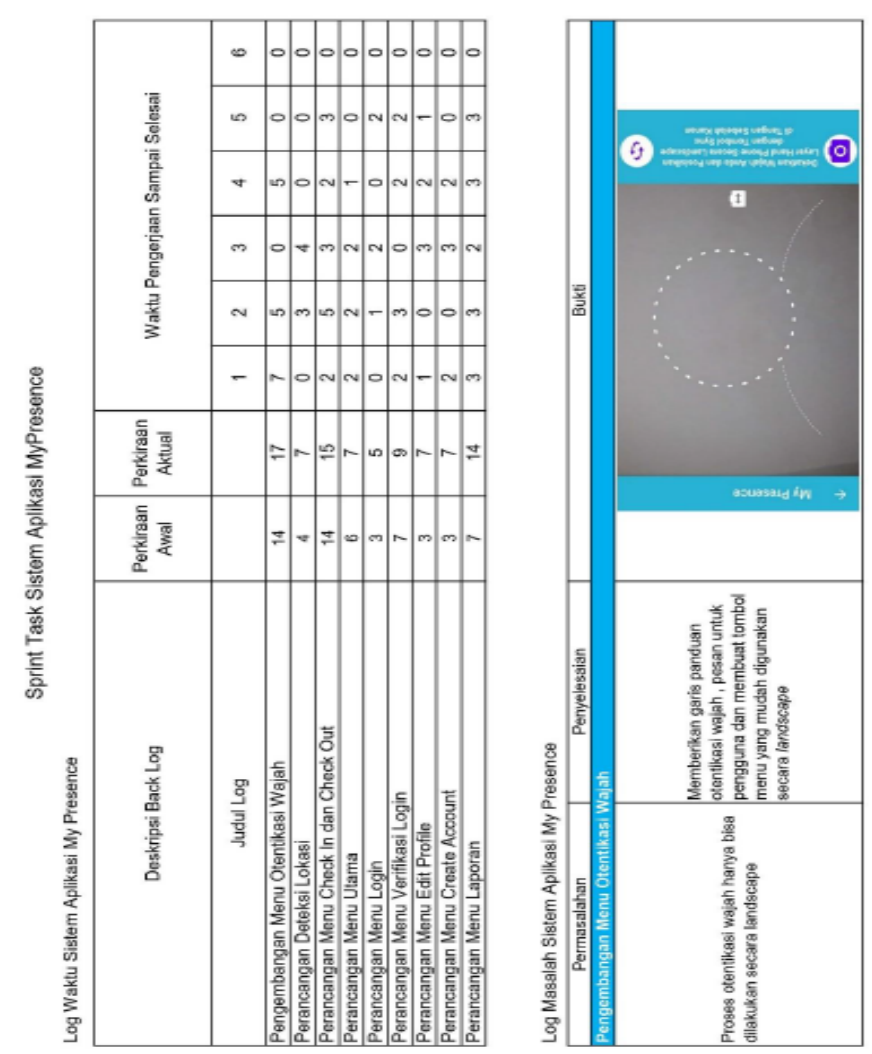

\section{Sprint Planning}

Menentukan prioritas sprint backlog yang kiranya lebih mudah dikerjakan terlebih dahulu, dari prioritas utama yang sudah ditentukan kami juga menentukan prioritas lain dalam kategori mudah untuk dikerjakan, seperti backlog untuk perancangan login aplikasi.

\section{Daily Scrum}

Mengevaluasi hambatan terjadi selama proses sprint berlangsung dan mencari solusinya karene pastinya ada esulitan dalam mengintegrasikan beberapa fitur sehingga kami mencari solusi terbaik agar sesuai dengan fungsi backlog tersebut dan sesuai dengan estimasi waktu yang diperkirakan.

\section{Sprint Review}

Melihat hasil dari sprint yang sudah dikerjakan sesuai waktu yang ditentukan. Jika product backlog yang kami kerjakan terlalu memakan waktu maka kami mengubah prioritas sprint backlog untuk mengerjakan product backlog yang kiranya lebih cepat diselesaikan, sehinga waktu yang dibutuhkan untuk menyelesaikan suatu product backlog bisa tepat waktu sesuai estimasi perkiraan awal. 


\section{Sprint Retrospective}

Mengevaluasi kinerja pada akhir setiap sprint tanpa membahas permasalahan teknis untuk meningkatkan kinerja di sprint selanjutnya. Tahan ini kami menguevaluasi permasalahan diluar kesulitan pengerjaan tapi lebih ke faktor eksternal yang kiranya menghambat pengerjaan aplikasi, seperti suasana lingkungan dan lain sebagainya.

\section{Increment}

Merupakan hasil dari semua product backlog yang telah selesai dikerjakan pada setiap sprint, memastikan sesuai dengan sprint backlog dan bisa digunakan. Sehingga meminimalisir terjadinya bug ketika aplikasi ini dijalankan oleh pengguna.

\section{HASIL DAN PEMBAHASAN}

Tahap selanjutnya setelah menentukan metode pengembangan aplikasi yaitu membuat perancangan sistem, yaitu membuat use case diagram, activity diagram serta sequence diagram untuk mengetahui alur aplikasi dan perancangan user interface yang diperlukan nantinya. Berikut ini adalah perancangan diagram yang dibuat dalam pengembangan aplikasi ini:

\section{A. Use Case Diagram}

Merupakan diagram yang menggambarkan hubungan antara use case, aktor dan relasinya. Use Case Diagram digunakan untuk membentuk perilaku sistem yang akan dibuat. Berikut ini adalah gambar use case diagram dari pengembangan sistem aplikasi absensi ini.

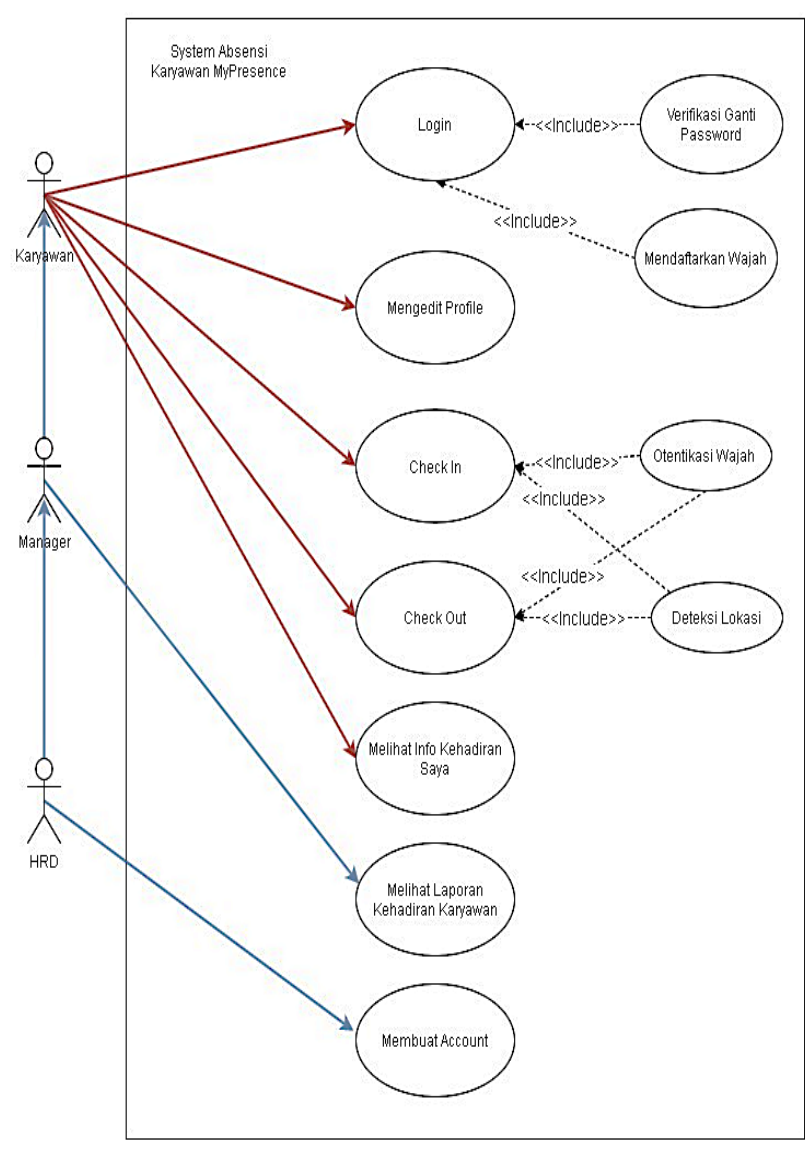

Gambar 2. Use Case Diagram

\section{B. Activity Diagram}

Merupakan suatu diagram yang menggambarkan aktifitas, objek, state, transisi state dan event, yang mana menjelaskan aliran kegiatan dalam program yang dirancang, bagaimana proses alir berawal, keputusan yang diambil dalam setiap alir dan bagaimana akhir dari aliran sistem. Berikut ini adalah gambar dari activity diagram untuk aktor $H R D$ yang mana memiliki hak otoritas tertinggi, dimana setiap case yang dilakukan oleh HRD mencakup case keseluruhan yang ada pada sistem.

Perbedaan activity diagram HRD dengan aktor manager yaitu untuk akses membuat akun baru dan perbedaan tampilan di menu laporan kehadiran karyawan, yang mana untuk manager hanya bisa melihat laporan dari divisi yang dipimpin saja, sedangkan untuk aktor karyawan tidak ada otoritas untuk mengakses menu laporan kehadiran karyawan seperti kedua aktor yang sebelumnya. 


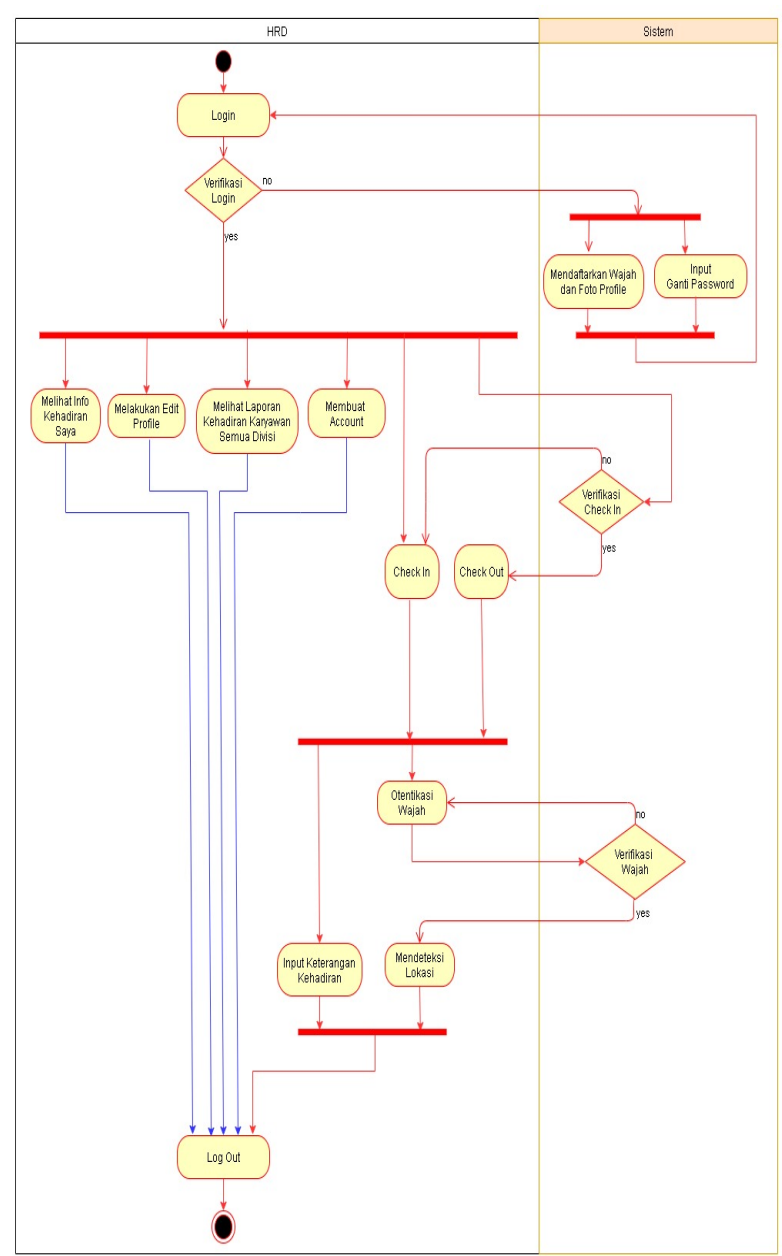

Gambar 3. Activity Diagram HRD

\section{Sequence Diagram}

Sequence Diagram merupakan suatu diagram yang menjelaskan interaksi objek yang disusun berdasarkan urutan waktu dan menunjukan komunikasi diantara objek - objek tersebut. Sequence Diagram digunakan untuk menjelaskan perilaku pada sebuah skenario, entitas dan sistem saat berinteraksi, termasuk pesan yang digunakan saat interaksi. Berikut ini adalah rancangan sequence diagram untuk proses membuat akun yang mana hanya bisa dilakukan oleh $H R D$.

Sequence Diagram ini terdiri dari HRD sebagai aktor, kemudian sistem melakukan verifikasi user yang digunakan untuk masuk jika user bukan dari departemen $H R D$ maka akses ditolak, jika benar maka diteruskan ke menu create account, kemudian sistem akan mengakses class RegisterActivity, dan user bisa melakukan input user baru yang kemudian hasil inputannya disimpan pada tabel $t b \_$users.

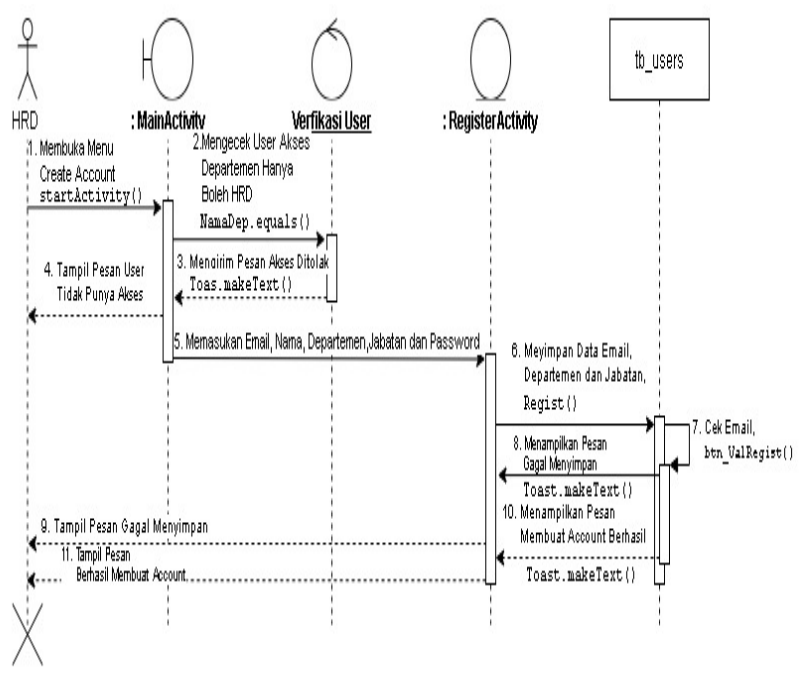

Gambar 4. Sequence Diagram Create Account

D. Hasil Implementasi

Tahap selanjutnya setelah dilakukan perancangan sistem, yaitu implentasi dari perancangan yang sudah dibuat sebelumnya. Berikut ini adalah hasil implementasi sistem aplikasi absensi yang dibuat.

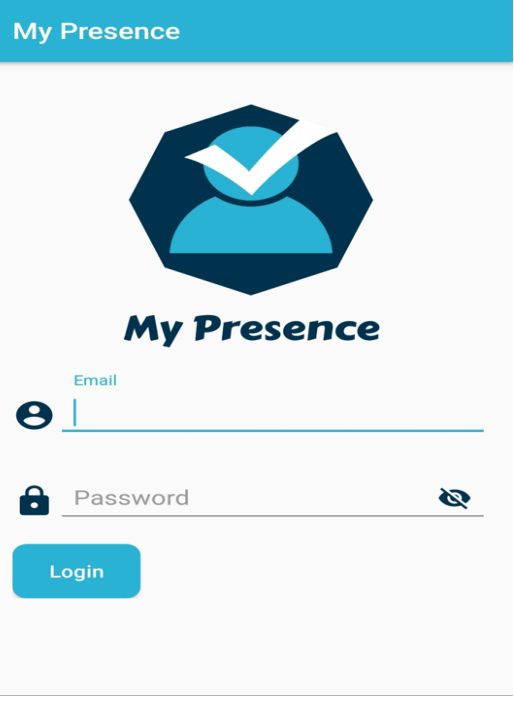

Gambar 5. Tampilan Login

Tampilan pada gambar 5, merupakan tampilan awal pada sistem aplikasi absensi ketika user akan menggunakan aplikasi, user harus memasukan username dan password yang sebelumnya sudah dibuatkan oleh $H R D$, kemudian user akan diarahkan untuk melakukan verfikasi akun jika user tersebut baru pertama kali menggunakan aplikasi ini, verifikasi yang harus dilakukan yaitu mendaftarkan wajah yang nantinya akan digunakan untuk proses otentikasi wajah dan foto 
profile, dan user juga bisa mengganti password akun tersebut. Akan ada pesan yang tampil jika username atau password yang dimasukan di menu login ini salah. Untuk form password juga ada fitur hidden password, yang bisa diaktifkan dengan menekan tombol eye di form tesebut.

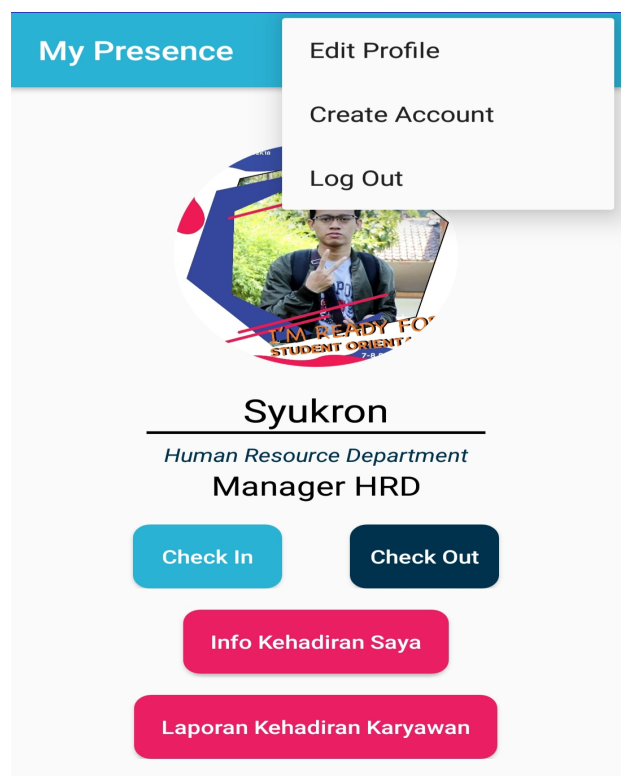

Gambar 6. Tampilan Menu Utama

Pada gambar 6, ini merupakan tampilan menu utama setelah user berhasil login, dimana tampilan diatas adalah tampilan untuk user dari departemen $H R D$ atau manager, untuk user karyawan menu untuk melihat laporan kehadiran karyawan akan dihilangkan dan menu create account akan dibatasi aksesnya hanya bisa diakses oleh user dari departemen $H R D$ saja. Ketika awal mengakses aplikasi ini untuk menu create account tampil disemua kategori user tapi hanya user dari departemen HRD saja yang bisa membuka menu tersebut, sementara user dari divisi lain tidak bisa membukannya yang mana akan muncul pesan tidak bisa membuka menu dan kemudian menu create account tersebut akan hilang setelah muncul pesan tersebut.

Pada gambar 7, merupakan tampilan menu check in untuk melakukan proses absensi kedatangan dengan melakukan otnetikasi wajah dan deteksi lokasi serta mengisi keterangan absensi pada kolom yang sudah disediakan. Untuk proses yang dilakukan untuk check in dan check out sama. Untuk deteksi lokasi hanya bisa dilakukan ketika user sudah melakukan otentikasi wajah, di akhir menu tersedia tombol untuk mengirim data hasil check in atau check out, tapi sebelum dikirim sistem akan mengecek apakah semua prosedur pada proses check in atau check out sudah dilakukan semua, jika ada satu saja yang kurang maka sistem tidak bisa mengirim data dan akan tampil pesan untuk melengkapi semua prosedur check in atau check out terlebih dahulu.

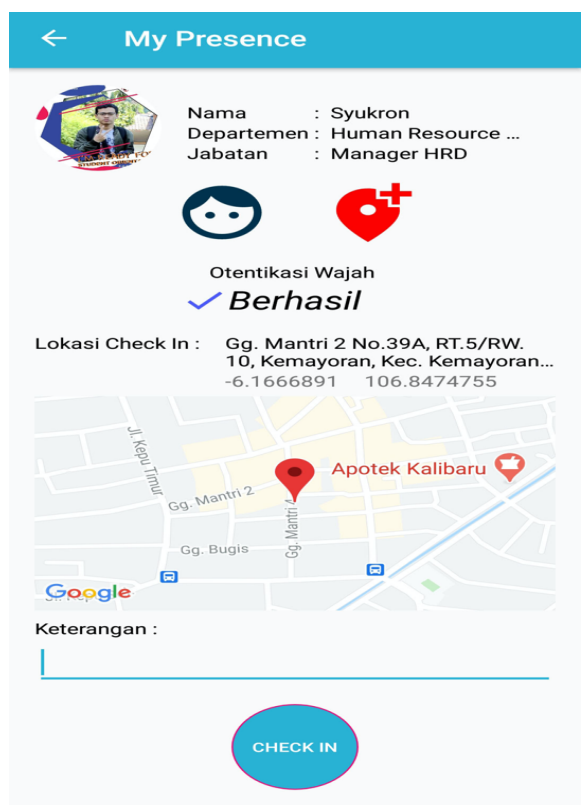

Gambar 7. Menu Check In

Pada gambar 8, merupakan tampilan menu otentikasi wajah, dimana hasil otentikasi wajah akan dikirimkan ke menu check in atau check out, karena menu ini hanya bisa dipanggil dari menu check in atau check out. Dalam melakukan otentikasi wajah yang perlu dilakukan pada menu ini yaitu memposisikan ponsel user dalam posisi landscape karena sistem aplikasi absensi ini untuk otentikasinya hanya bisa dilakukan secara landscape, dengan posisi tombol sync di sebelah kanan atas. Tombol sync berguna untuk melakukan singkronisasi ulang file wajah yang sebelumnya sudah di daftarkan, setelah proses singkronisasi ulang selesai baru tombol take picture atau tombol kamera akan muncul untuk memulai proses otentikasi wajah. Untuk keberhasilan proses otentikasi usahan posisi pencahayaan yang cukup dan wajah menghadap kamera. Percobaan otentikasi wajah dengan status berhasil, yang sudah dilakukan yaitu dengan 
kondisi normal dimana wajah menghadap kedepan dan pencahayaan yang cukup dengan tambahan aksesoris wajah kaca mata.

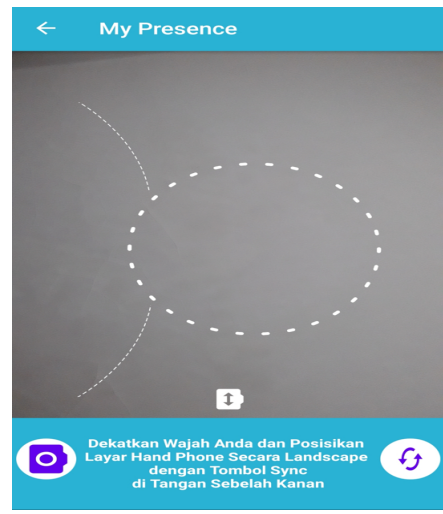

Gambar 8. Menu Otentikasi Wajah

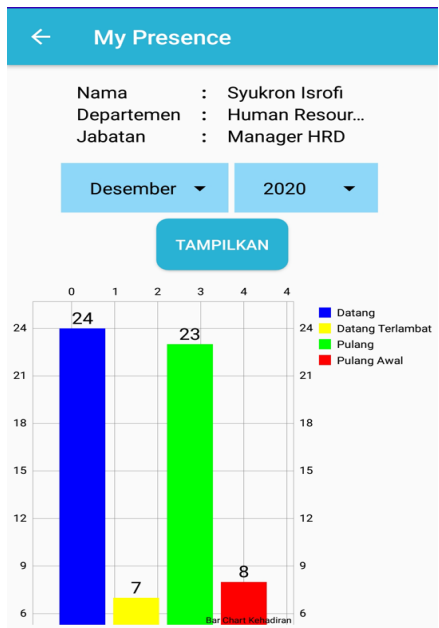

Gambar 9. Menu Info Kehadiran Saya

Pada gambar 7, merupakan tampilan menu info kehadiran saya, yang merupakan menu untuk melihat hasil proses check in atau check out, dari masing - masing user, berdasarkan user login masing - masing, dengan pilihan filter bulan dan tahun untuk melihat hasil absensi user tersebut berdasarkan bulan dan tahun yang dipilih. Untuk warna pada diagram batang pada menu tersebut, mewakili keterangan check in atau check out nya, dimana untuk warna biru mewakili untuk check in datang tepat waktu, warna kuning untuk check in terlambat, hijau untuk check out tepat waktu, dan merah untuk check out atau pulang lebih awal.

Pada gambar 10, merupakan tampilan menu Laporan Kehadiran Karyawan, yang merupakan menu untuk melihat hasil proses check in atau check out, dari departemen atau jabatan tertentu, khusus user dari departemen $H R D$ bisa mengakses semua departemen dan semua jabatan.

Untuk warna pada diagram batang pada menu tersebut, mewakili keterangan check in atau check out nya, dimana untuk warna biru mewakili untuk check in datang tepat waktu, warna kuning untuk check in terlambat, hijau untuk check out tepat waktu, dan merah untuk check out atau pulang lebih awal. Pada bagian bawah menu terdapat daftar nama dari masing - masing diagram batang sesuai warnanya, kegunaan dari daftar nama ini yaitu untuk memberikan rincian user / karyawan yang masuk dalam kategori masing - masing diagram batang tersebut.

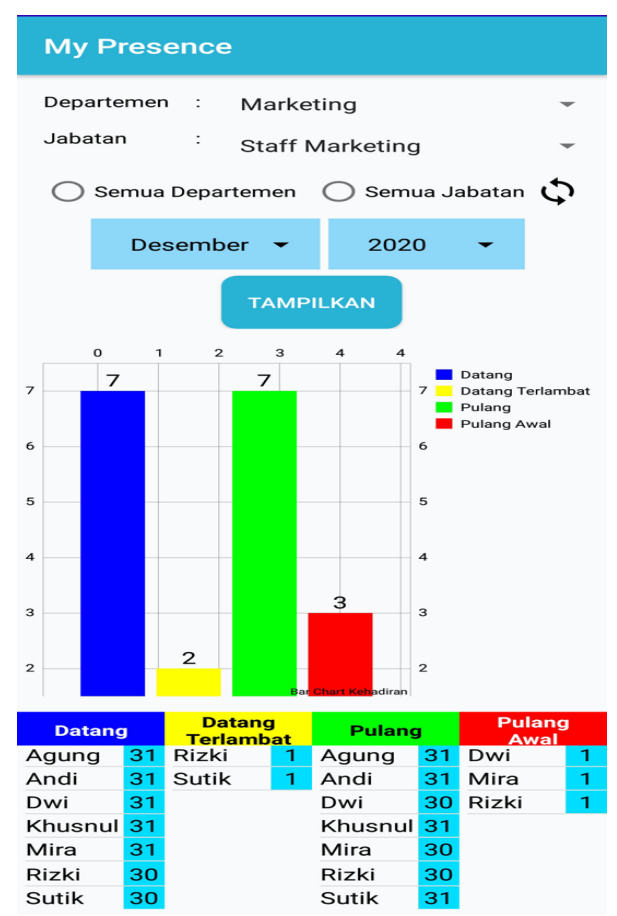

Gambar 10. Menu Laporan Kehadiran Karyawan

E. Hasil Pengujian

Tahap pengujian sistem dilakukan dengan pendekatan black box testing, black box testing adalah pengujian yang dilakukan sepenuhnya dengan hanya menilai kebutuhan dan spesifikasi software. Black box testing cukup meninjau input dan output sistem software tersebut tanpa pengetahuan tentang internal programnya. 


\begin{tabular}{|c|c|c|c|c|c|}
\hline \multicolumn{6}{|c|}{ Survei Black Box Testing Sistem Aplikasi My Presence } \\
\hline No. & Test Case & Skenario Uji & $\begin{array}{l}\text { Hasil yang } \\
\text { diharapkan }\end{array}$ & Hasil Uji & Kesimpulan \\
\hline 1. & $\begin{array}{l}\text { Menampilkan } \\
\text { Mlenu Login }\end{array}$ & Nedakukan Login & $\begin{array}{l}\text { Menampikan } \\
\text { Menu Utama }\end{array}$ & & Valid \\
\hline 2. & $\begin{array}{l}\text { Menampilkan } \\
\text { Menu Verflcasi } \\
\text { Passwerd }\end{array}$ & $\begin{array}{l}\text { Nondaftarkan } \\
\text { Wajah dan Edit } \\
\text { Passward }\end{array}$ & $\begin{array}{l}\text { Menampilkan Meru } \\
\text { Login, Wajah } \\
\text { Teroatlar dan } \\
\text { Password terganti }\end{array}$ & & Valid \\
\hline 3. & $\begin{array}{l}\text { Menampilkan } \\
\text { Menu EGit Profile }\end{array}$ & $\begin{array}{l}\text { Nolaloukan Edt } \\
\text { Nama dan } \\
\text { Password }\end{array}$ & $\begin{array}{l}\text { Menampilkan Meru } \\
\text { Utama, Nama den } \\
\text { Password Bahthasi } \\
\text { dode }\end{array}$ & & Valid \\
\hline 4 & $\begin{array}{l}\text { Mensminikas } \\
\text { Meru Check In }\end{array}$ & $\begin{array}{l}\text { Neniifl tum ivul } \\
\text { menu check in }\end{array}$ & $\begin{array}{l}\text { Menaminilisan Meiu } \\
\text { Check in }\end{array}$ & & vava \\
\hline 5. & $\begin{array}{l}\text { Menampilkan } \\
\text { Meru Check Out }\end{array}$ & $\begin{array}{l}\text { Nomifh tombol } \\
\text { menu check out }\end{array}$ & $\begin{array}{l}\text { Menampilkan Menu } \\
\text { Check Out }\end{array}$ & & Valid \\
\hline 6. & $\begin{array}{l}\text { Mernampilkan } \\
\text { Meru Otentkasi } \\
\text { Wajah }\end{array}$ & $\begin{array}{l}\text { Neminh Tombol } \\
\text { Olemikrssi Wajah }\end{array}$ & $\begin{array}{l}\text { Menampilkan Menu } \\
\text { Otentiksai Wajah }\end{array}$ & & Valld \\
\hline 7. & $\begin{array}{l}\text { Melhat Lokasi } \\
\text { Terkin }\end{array}$ & $\begin{array}{l}\text { Nemili Tombol } \\
\text { Dalaksi Lokasi }\end{array}$ & $\begin{array}{l}\text { Menampilkan lokasi } \\
\text { tenkini }\end{array}$ & & Valid \\
\hline 8. & $\begin{array}{l}\text { Menampilkan } \\
\text { Meru Into } \\
\text { Kenadran Saya }\end{array}$ & $\begin{array}{l}\text { Nemifh tombol } \\
\text { menu Into } \\
\text { Kehadiran Saya }\end{array}$ & $\begin{array}{l}\text { Menampilkan Meru } \\
\text { Infto Kenadran } \\
\text { Saya }\end{array}$ & & Valid \\
\hline 9. & $\begin{array}{l}\text { Mernampilkan } \\
\text { Meru Laparan } \\
\text { Kenadoran } \\
\text { Kayswann }\end{array}$ & $\begin{array}{l}\text { Nomiih tambol } \\
\text { menu Lapcran } \\
\text { KKhasiran } \\
\text { Karyswant }\end{array}$ & $\begin{array}{l}\text { Menamplikan Menu } \\
\text { Laporan Kehodiran } \\
\text { Kayyawan }\end{array}$ & & Valid \\
\hline 10. & $\begin{array}{l}\text { Menampilkan } \\
\text { Meru Create } \\
\text { Account }\end{array}$ & $\begin{array}{l}\text { Neiciouikan } \\
\text { registrasi account } \\
\text { baru }\end{array}$ & $\begin{array}{l}\text { Menampilkan Meru } \\
\text { Login, acosunt } \\
\text { berhasi dbuat }\end{array}$ & & Valid \\
\hline
\end{tabular}

Gambar 11. Check List Survei Black Box Testing

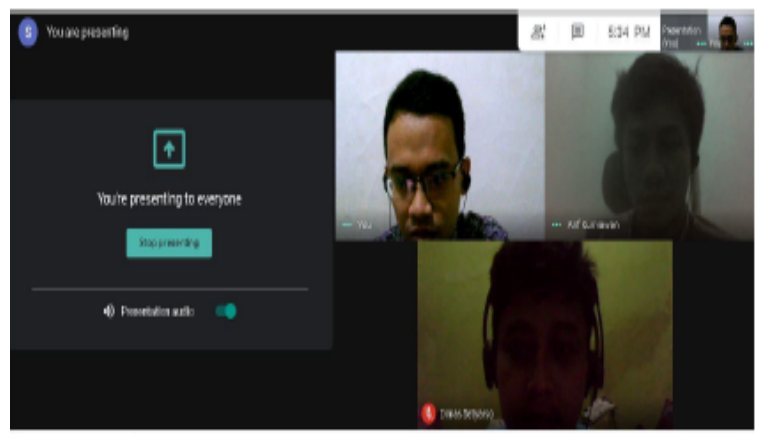

Gambar 12. Demo Aplikasi Dengan Survei Black Box Testing

Dari survei dengan metode black box testing ini didapatkan hasil bahwa aplikasi bisa menampilkan aksi sesuai yang diharapkan, seperti ketika menekan tombol untuk deteksi lokasi pada menu aplikasi, aplikasi berhasil menampilkan lokasi aktual dari user yang menekan tombol tersebut.

Berikut adalah proses demonstrasi otentikasi wajah dengan ponsel Android dengan posisi ponsel landscape, karena proses otentikasi wajah untuk aplikasi ini baru bisa dilakukan dengan posisi horizontal dengan pencahayaan yang normal.

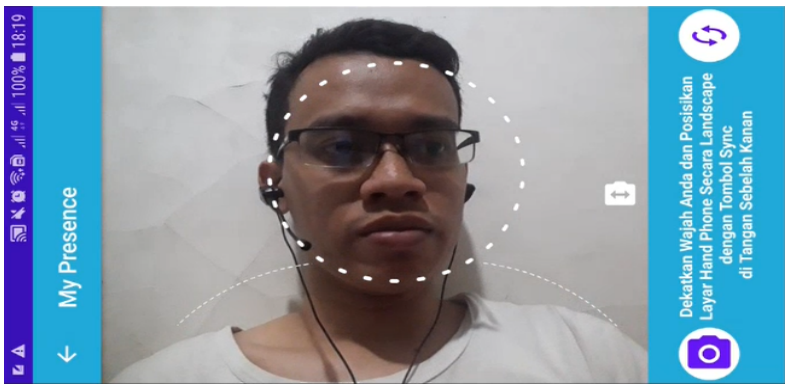

Gambar 13. Demo Aplikasi Otentikasi Wajah Menggunakan Kaca Mata

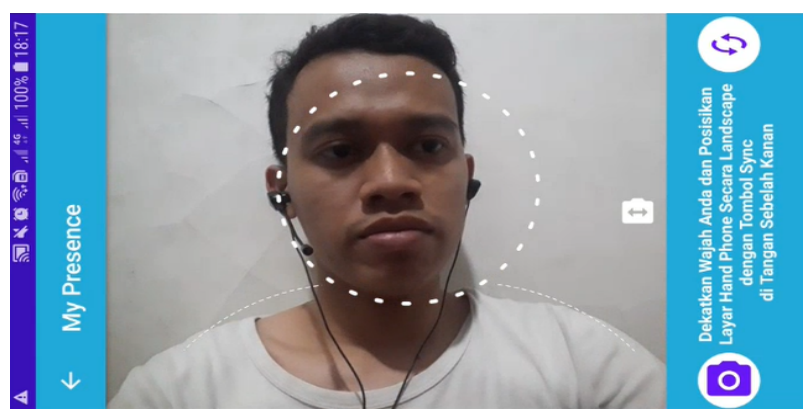

Gambar 14. Demo Aplikasi Otentikasi Wajah Tanpa Kaca Mata

Proses otentikasi dilakukan dengan membandingkan wajah yang menggunakan kaca mata dan tanpa kaca mata, hasil dari otentikasi wajah ini menunjukan keberhasilan yang sama. Faktor lain yang menunjang otentikasi wajah ini berhasil karena kondisi penerangan yang cukup, ketika proses otentikasi dilakukan dengan kondisi penerangan yang ekstrim seperti terlalu gelap maka tidak bisa menunjukan hasil verifikasi wajah yang benar.

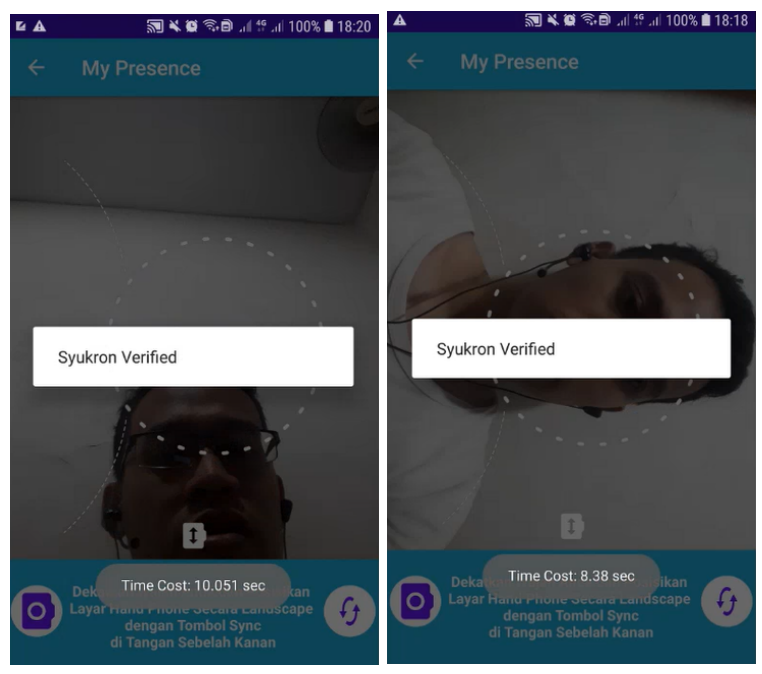

Gambar 15. Hasil Verifikasi Dengan atau Tanpa Kaca Mata 


\section{KESIMPULAN DAN SARAN}

\section{A. Kesimpulan}

Berdasarkan hasil implementasi dari aplikasi sistem absensi berbasis android menggunakan otentikasi wajah dan deteksi lokasi, sistem aplikasi absensi ini dibuat untuk memudahkan memantau kehadiran karyawan CV. Atmosfer IT Consultan yang bertugas dilapangan, dengan basis sistem operasi Android, serta untuk proses deteksi lokasi sistem aplikasi absensi ini harus terkoneksi internet dengan mengandalkan Google Maps API yang kemudian di reverse menjadi alamat.

Sistem aplikasi absensi ini juga menggunakan bantuan library Open CV dan Dlib library untuk melakukan verifikasi wajah, yang mana proses otentikasi wajah mengandalkan foto yang sudah didaftakan terlebih dahulu dan tersimpan di ponsel yang terinstal sistem aplikasi ini, dari hasil otentikasi wajah untuk kehadiran, sistem aplikasi absensi ini bisa menampilkan laporan dari hasil proses absensi, berupa bentuk grafik batang dengan memanfaatkan library dari MPAndroid Chart dan Volley library untuk mengambil data dari server dan ditampilkan ke ponsel pengguna.

\section{B. Saran}

Dalam pengembangannya sistem absensi berbasis android dengan otentikasi wajah dan lokasi ini masih memiliki kekurangan, yang mana saran pengembangan sistem absensi ini lebih lanjut antara lain :

1. Adanya sistem notifikasi sebagai pengingat waktu harus melakukan absensi kehadiran agar tidak terlewat.

2. Disarankan adanya proses persetujuan oleh manager atau kepala divisi disistem aplikasi absensi ini, jika karyawan melakukan absensi pulang lebih awal.

3. Bisa melakukan proses otentikasi wajah secara online tanpa menyimpan, file foto wajah di penyimpanan lokal ponsel.
4. Untuk menu info kehadiran dan laporan kehadiran ada filter periode tanggal dan bisa export ke file lain seperti excel atau pdf.

5. Disarankan kedepannya ada pengamanan dan deteksi terhadap aplikasi ketiga untuk mencegah deteksi lokasi palsu.

\section{DAFTAR PUSTAKA}

[1] R. M. Akbar and N. Prabowo, "Aplikasi Absensi Menggunakan Metode Lock GPS Dengan Android Di PT. PLN (Persero) App Malang Basecamp Mojokerto," Majapahit Techno, vol. V, no. 9, pp. 5563, 2015 .

[2] A. Juansyah, "Pembangunan Aplikasi Child Tracker Berbasis Assisted - Global Positioning System (AGPS) Dengan Platform Android," Jurnal Ilmiah Komputer dan Informatika (KOMPUTA), vol. I, no. 8, pp. 1-8, 2015.

[3] I. P. P. Yana Wardana, I. A. D. Giriantari and M. Sudarma, "Aplikasi Verifikasi Wajah Untuk Absensi Pada Platform Android Dengan Menggunakan Algoritma Fisherface," Teknologi Elektro, vol. XV, no. 7, pp. 45-51, 2016.

[4] S. and K. , "Analysis of Face Recognition Algorithm: Dlib and OpenCV," JITE (Journal of Informatics and Telecommunication Engineering), vol. IV, no. 12, pp. 173-184, 2020.

[5] T. F. Harumy, J. Sitorus and M. Lubis, "Sistem Informasi Absensi Pada PT. Cospar Sentosa Jaya Menggunakan Bahasa Pemprograman Java," Jurnal Teknik dan Informatika, vol. V, no. 8, pp. 63-70, 2018.

[6] P. Mei, "Metodologi Pengembangan Sistem Informasi," in Metodologi Pengembangan Sistem Informasi, Salatiga, LP2M IAIN Salatiga, 2020, p. 105.

[7] N. Ruseno, "Implementasi Scrum Pada Pengembangan Aplikasi Sistem Reservasi Online Menggunakan PHP," JURNAL GERBANG, vol. IX, no. 8, pp. 8-15, 2019.

[8] opencv.org, "About," -. [Online]. Available: https://opencv.org/about/. [Accessed 1911 2020].

[9] dlib.net, "Introduction," 2015. [Online]. Available: http://dlib.net/intro.html. [Accessed 1911 2020]. 